\title{
LANGUAGE IN THE CONFLICT OF LAWS: QUALIFICATION, MEANING OF CONCEPTS. THE CASE OF MARRIAGE
}

\begin{abstract}
According to E. G. Lorenzen, the international theory of the conflict of laws rests almost wholly on fiction. The discipline of conflict of laws is created by a huge number of national internal laws and quite a large number of international instruments. Concepts used there are interpreted in many ways illustrating the variety of legal solutions and values. Some of the instruments facilitating the correct application of law are unregulated. One of them is qualification, which starts the process of indication and application of the proper law and assists in its completion.

Keywords: qualification, public order clause, legal concept, marriage, private international law, conflict of laws.
\end{abstract}

\section{Introduction}

The function of the conflict of laws is to indicate the proper law. Consequently, the law indicated should be applied. Depending on the legal system, the source of choice of law and its application is the normative obligation - derived from the principle of equality of states and their legal systems, but also comity, the conviction that such action is an expression of justice and accords with social expectation (Robertson, p. 29, following Lorenzen, p. 260-270). Still, as R. A. Pascal comments regarding the American legal system, the court may either decide arbitrarily without reference to any system of law, or apply its own law exclusively, or refer the matter to the system of law with which the case seems to have the closest association (Pascal, p. 716). The reason for the creation of conflict of law solutions may be the existence of different legal systems and the need to protect entities associated with them. Differences in legal regulations entail the existence of institutions known only to certain laws but also other perceptions of institutions being regulated everywhere. This means that the meanings of 
concepts adopted for these institutions (although the concepts themselves are the same) do not have a uniform content. The most paradoxical, from the point of view of application, is a situation where the facts correspond with the content adopted for a given concept but at the same time do not correspond with it: for example, when the relationship between two persons is not a marriage from the perspective of the law of the forum but is a marriage from the point of view of the law indicated. Therefore at least a couple of questions appear: about the method of qualification in relation to concepts and also whether the correct indication of law should mean the situation in which we apply the norm of the forum to the facts (referred to as marriage in the indicated law), when its scope does not include marriage.

\section{Qualification}

Qualification is a tool that makes it possible to realize the basic functions of conflict of laws. Besides identifying the proper law for a particular circumstance, it should also lead to identification of the specific norm of that law that needs to be applied. In light of the theories adopted in states using a civil law system, depending on the method of qualification adopted, it is possible to apply a single law to interpret concepts contained in the hypothesis of a conflict rule or to use more than one. Assuming that the method of dealing with qualification postulated in the doctrine is the method of application of the collision lex fori, we consider the international function of conflict of laws important. Therefore, we create a fiction of the existence of a universal set of the same meanings assigned to concepts in the countries in which this method of qualification is applied. But in fact this idea is false and belongs rather to a different - autonomous - theory. So, however vague it sounds, the concept of marriage should be interpreted as assumed in the internal law of the forum, while also remembering the international nature of the conflict of laws - and therefore broader than the law implies. Then we will avoid a situation in which the same set of facts will be considered and not be considered as a marriage at the same time. The application of the lex fori and lex causae methods leads to a different result, because in each of them we will use two laws, unless we extend the first one (the law of the forum) to the entire law-making process and apply it also to secondary qualification. However, as a rule, the lex causae method is practiced after the law has been indicated, while lex fori-to the interpretation of the concepts contained in the law of the forum. If both methods are used in the case, one situation may be and also not be considered as marriage. In the opinion 
of E. Bartin and F. Kahn, who first raised the problem of qualification, it should be, with minor exceptions, conducted on the basis of lex fori (Bartin, p. 225-255, Kahn, p. 111). These exceptions referred to the interpretation of the concept of immobility and, in real terms, the distinction between immovable and movable property, which was subjected to the law of the situs and of the concept of the place of contracting (therefore to the notions used in the hypothesis of the collision norm, but also in the connecting factor). In turn, F. Despagnet was of the opinion that the law governing the legal relationship (lex causae) should be applied to qualification, strictly speaking - to control it (Despagnet, p. 253-273).

The theories concerning qualification, also called classification or characterisation (System, p. 303), are a little bit different in common law countries. English law for example, distinguishes between the qualification of the cause/source of the claim (cause of action) and the rule of law, which is the second stage in the process of indicating the proper law. The application of the first is dictated by the assumption that the structure of each law consists of norms ranked according to certain system categories constituting the source of the claim (Hayward, p. 7). According to P. North and J.J. Fawcett, the court is faced with the need to determine the juridical nature of the claim and to decide it or, otherwise, to assign the claim arising from the facts to the appropriate legal category and then decide it (Hayward, p. 36). This means that in order to move on, one should first determine where (in what category) the cause of the claim lies - in contractual obligations, torts, matrimonial matters, etc. The importance of the category distinction is illustrated by the judgment in Raiffeisen Zentral Osterreich AG v Five Star General Trading LLC [2001] QB 825, in which it was considered whether the source of the claim is a contract or a right in rem. Depending on the decision of the court, there was a later indication of the proper law - a variant, depending on the connecting factors used for these categories of cases.

It is important, evidently, to specify the method of conducting qualification, as the classification of legal categories may be various in different states. In the absence of legal regulation and diversity of judgments (Tezcan v. Tezcan [1992] 87 DLR (4th) 503, Re Musurus's Estate [1936] 2 All ER 1666, Cf Re Martin, Loustalan v. Loustalan [1900] P 211, (Maltese Marriage case) Anton v. Bartolo Clunet (1891) 1171, Macmillan Inc. v. Bishopsgate Trust (No 3) [1996] 1 WLR 387, G\&H Montage GmbH v. Irvani [1990] 1 WLR 667, De Nicols v. Curlier [1900] AC 21, Re Berchtold [1923] 1 Ch 192, Leroux v. Brown (1852) 12 CB 801, Mahadervan v. Mahadervan [1964] P 233, [1962] 3 All ER 1108, Cf Bernkrant v. Fowler 55 Cal 2d 558, 
360 P2d 906 (1961), Anderson v. Equitable Assurance Society of the United States (1926) 134 LT 557, Re Cohn [1945] Ch 5, Re Priest [1944] Ch 58, [1944] 1 All ER 51, Re Maldonado's Estate [1954] P 223, [1953] 2 All ER 300, Re Fuld's Estate (No 3) [1968] P 675, Ogden v. Ogden [1908] P 46, Simonin v. Mallac (1860) 2 Sw\& Tr 67, Lodge v. Lodge (1963) 107 Sol Jo 437, Re Mitchell, Hatton v. Jones [1954] 2 All ER 246, Re Hanley's Estate [1942] P 33, [1941] 3 All ER 301, Re Barnett's Trust [1902] 1 Ch 847, Adams v. National Bank of Greece and Athens [1958] 2 QB 59, [1958] 2 All ER 3, Phrantzes v. Argenti [1960] 2 QB 19, General Steam Navigation Co. v. Guillou (1843) 11 M\&W 877, Re Doetsch [1896] 2 Ch 836, Huntington v. Attrill [1893] AC 150, Re Wilks [1935] Ch 645, Re Korvine's Trusts, Levashoff v. Block [1921] 1 Ch 343, Metal Industries (Salvage) Ltd. v. S T Harle (Owners) 1962 SLT 114), it is difficult to accept a postulated unambiguous standpoint for all cases. Nevertheless, the doctrine emphasizes that the very nature of the conflict of laws makes qualification on the basis of the law of the forum erroneous.

It is also emphasized that the method of interpretation should be broader than in domestic cases, that the lack of such behaviour makes it impossible to resolve cases concerning institutions unknown to English law or to notice legal categories that are not identical to English ones (Robertson, p. 33). It is suggested to take into account institutions present in foreign laws, to take advantage of comparative studies (Beckett, p. 59) or of general international principles, understood as principles of jurisprudence and comparative law (Robertson, p. 25), but also of the proper international order and justified expectations of social life in a specific case, and even to conduct qualification in accordance with European Union law (Jacob Handte GmbH v Traitements Mécano-Chimiques des Surfaces [1992] ECR 1-3967, Hayward, p. 7).

What is interesting, at the beginning of the 20th century the House of Lords applied a broad interpretation of the marriage contract when deciding about the proper law for qualification - either its own or that of France (De Nicols v Curlier [1900] AC 21). From this, it follows that as in civil law states, the lex fori, lex causae, and collision lex fori methods of qualification can all be taken into consideration. The second specifically is acceptable when, according to all potential laws proper for the resolution of the case, the juridical determination of the nature of the claim is the same while at the same time being different under English law (Robertson, p. 39, Lorenzen, p. 268). The question of method also applies to the qualification of the rule of law. Usually problems in this matter will relate to the distinction between material law and procedure, but also to the question whether it is 
appropriate to apply rules that emanate from some legal policy outside the state in which they are in force or in relation to entities connected with other countries. It is also undeniable that the use of foreign law for qualification is unacceptable if it would be contrary to English public policy doctrine or would undermine the basic principles of English law (Robertson, p. 42).

In 1940, A. H. Robertson summarized the theories regarding qualification. By analyzing the cases indicated by E. G. Lorenzen, in which the court should have conducted qualification, he identified its three different types (referring to them as classes) while also taking into consideration the order of activities provided while qualifying. In the first class he placed cases in which the qualification had to be applied to the juridical nature of the problem presented to the court - and thus to assign the case to the appropriate category. The result was an indication, e.g. this is a contract. Cases in which the connecting factor should have been subjected to qualification were placed in the second class, while in the third were cases in which qualification was to be applied to norms indicated as proper (the effect was to distinguish norms that were part of substantive law from those that made up the procedure) (Robertson, p. 8-12).

Whereas Lorenzen referred rather to the interpretation of the concepts contained in the norms, Beckett noted the need to determine whether not only the facts but also the legal norm and the right derived from it, fell into one of the adopted categories of analytical jurisprudence. According to him, both facts and legal norms were the subjects of qualification (Lorenzen, p. 268-282 / Beckett, p. 46). This influenced the assignment of activities to each class that differed from those expressed in Lorenzen's. The first class was provided for cases that did not concern the qualification of the norm or the institution of law - the activity was to apply to the facts the category proper for the conflict of laws (it included determination of the juridical nature of the problem, but also what Lorenzen accepted as the qualification of the connecting factor). In the second class there were activities involving the qualification of the forum norm or legal institution, in the third - foreign law (Becket, p. 61).

The issue of subsequent steps, characteristic for the conflict of laws, in the context of the necessity of qualification was also of interest to J. D. Falconbridge. According to him, the court at first performs qualification of the claim or the facts (stage of qualification), then selection of applicable law using methods determining the suitable connecting factor (stage of selection), and finally delimitation and application of the applicable law (stage of application of law). At each of these stages, the court conducts the qualification (Falconbridge, p. 239, 547). Cheshire, on the other hand, calls the 
first stage the primary qualification, as the fitment of the claim in the right legal category, and the third - the secondary qualification, which takes place after indication of the proper law (Robertson, p. 22-23, Cheshire, p. 24-45).

Qualification, as defined by M. Pazdan as an interpretation of expressions defining the scope of the conflict of law rule taken to establish the conditions for its application (the interpretation of terms and subsumption) is, of course, much more complicated in the case of ambiguous concepts (Pazdan, p. 76). Lorenzen, seeing as such in the second decade of the 20th century, perceived nationality/citizenship, domicile, place of conclusion/performance of the contract, place of the commission of a tort, immobility/mobility, capacity, form, substance/procedure (Lorenzen, p. 247). Until recently 'motherhood' and 'marriage' were definitely not considered to be such concepts. The unambiguity of the first expression was dictated by the nature and physiology of a man, that is until the progress of medicine made it possible to carry out artificial procreation. The unambiguity of the second expression lay in the fact that historically it related to the coming together of two people of opposite sex - the issue of its formal or sacramental character was not always so obvious. Since both concepts have lost the value of universality, qualification is now much more important, especially when we consider two circumstances regarding the qualification itself and, more broadly, the conflict of laws. The first is the fact that qualification is very rarely subject to legal regulation. It possibly means that the legislature leaves the freedom in this matter to the recipients of the legal norms. The second is that private laws (and collision law as such) exist to protect the interests of entities (natural and legal persons), even in confrontation with the state and its institutions. While we are resolving the matter of private law, we are to protect the interests of the participants, not the state in which the matter is resolved. This means the possibility of applying provisions different from those in force in the forum and interpreting the terms in a different way from that adopted in the forum's internal law.

\section{Public order clause}

In real terms the application of foreign law does not arouse too much emotion and is generally a popular and undisputed practice of the courts. At the same time a foreign law is usually different from that of the forum. Collision law most probably arose owing to these differences. A consequence of its performance, having regard to protection of the parties' interests in a legal relationship, is the application of a law most closely connected with 
the case. This concept is justified on the grounds of both conflict of laws and private law. Foreign law, from the standpoint of the forum can be culturally distant, of different judicial tradition, values, principles, and legal solutions. In the context of collision law, foreign law, if chosen, should mean a law better protecting someone's interests. But, somewhat paradoxically, at the same time it should be the law connected with the case, not necessarily one containing a solution beneficial to the party. The concept of applying the law most connected with the case derives from Friedrich C. von Savigny's theory of law in force in the place where the legal relationship was anchored - it has become a fundamental collision tool, either as one of the methods of choice of law, general rule, or just a corrective clause. The forum's collision law indicates any law. Note - it indicates, it does not evaluate. Consequently, since the indicated law could transpire to be the least democratic and/or the most restrictive in the sphere of shaping the legal situation of individuals, it is unclear if the mechanics of indicating a proper law harmonize with the interests of the forum and its legal values. The conflict rule does not authorize evaluation of the foreign law, nor does it contain a mechanism that allows this to be done. The norm does not authorize a court to take any action other than apply the law indicated. The collision law may contain unilateral norms, which allow applying only the rules of the forum law for certain cases. Such cases reflect the conviction of the greater value of own law, and the necessity to make it more privileged in some sensitive spheres of social relations. When utilised, this provision can eliminate the application of foreign law (Bagan-Kurluta, p. 168-177).

Most probably, however, the egalitarian concept of choice of law would in any event not be accepted without leaving a legal gate that allowed one to refuse the application of a foreign law. This gate, or so-called safety flap, reflects the nature of the institution to be used in situations where values considered important in the forum are perceived to be under threat. The clause is a compromise between the unconditional application of the proper law and using nothing but the law of the forum. Thus, should the application of a foreign law pose potential controversy, the ability to apply the clause eliminates that fear. Because the application of the public order clause follows indication of a foreign law as being the proper law, the application of the collision norm and the indication mentioned are the first steps in a quite complicated process. At this stage one cannot claim its application. Identification of the specific foreign legal provision to be applied comes first. The next step is to assess the potential effects of its application. This enables the foreign provision to be evaluated in terms of its compliance or non-compliance with the forum law. If the potential effects will be contrary 
to the basic principles of the forum law, the conditions for the application of the clause will be met. If the potential effects are not contradictory to the principles of the forum, then no basis exists to reject application of the foreign rule (Sośniak, p. 179-187).

\section{Facts and solutions. Interaction between qualification and the public order clause}

Hypothetically, let us say that the court is to resolve the case of a nontraditional same-sex marriage concluded abroad by two individuals of different citizenships and having the same foreign location as the place of habitual residence. In the first instance, due to the foreign elements included in the known facts, connecting the situation with more than one law (the law of the forum), the court has to determine the proper law to resolve the case. To proceed with indication of the law, the court should begin from qualification, and therefore assess in what way the collision norm fits the facts (an hypothesis of which the norm contains hypothetical facts) and interpret the concepts provided in the conflict rule. In this case, the notion of marriage will be the subject of interpretation.

As Polish sources of collision law, the 2011 Act of Private International Law (hereinafter referred to as 2011 PIL) gives no directions as to the method of qualification; the court will make an independent decision in the choice of method. Generally, there are two possible solutions.

The first lies in acceptance of the idea that the meanings of the concepts contained in the conflict of law rules correspond with the meanings attributed to them under Polish law. It follows that the concept of marriage should be interpreted as referenced in art. 18 of the 1997 Polish Constitution, i.e. as a relationship between a woman and a man. Therefore, the facts cannot be assigned to any of the hypotheses of collision norms from that part of 2011 PIL related to matrimonial matters. The search for another collision norm may only lead to the part of the act dedicated to obligations, and from there, based on its art. 28.1, to Regulation (EC) No 593/2008 of the European Parliament and of the Council of 17 June 2008 on the law applicable to contractual obligations (Rome I). It does not regulate relations arising out of family relationships or relationships deemed by the law applicable to such relationships to have comparable effects, including maintenance obligations, as well as obligations arising out of matrimonial property regimes; property regimes of relationships deemed by the law applicable to such relationships to have comparable effects to marriage, wills, 
and succession - which art. 1.2 (b) and (c) of the Regulation clearly shows. Assuming that both the 2011 PIL and the Rome I Regulation lack a collision norm to be applied in cases involving same-sex marriage, in order to indicate the applicable law it will be necessary to use the norm of art. 67 from 2011 PIL, which provides that in absence of indication of the law applicable in this act - specific provisions, ratified international agreements in force in the Republic of Poland and European Union law - a relationship covered by the scope of the act should be governed by the law of the state with which this relationship is most closely connected.

The second solution consists in accepting the idea that the meanings of the concepts contained in the conflict of law rules should be attributed to the content resulting from Polish law, while at the same time taking into account the international function of conflict of laws. It means that the concept of marriage will cover a heterosexual relationship, but also a samesex relationship, if it is deemed a marriage not a registered partnership. Then, depending on what aspect of the marriage the case concerns, the court will look for a conflict rule to apply in that part of 2011 PIL covering matrimonial matters.

In each of these situations, in the indicated foreign law, a provision may be found, of which the effects of application will reconcile with the constitutional norm of art. 18. If it is acknowledged that it contains a basic principle of the Polish legal order, there will be grounds for applying the public order clause. In this way, if a Polish rule will be introduced instead of a foreign rule, the matter may not be resolved in accordance with the parties' expectations. The same, of course, applies if the court will indicate the Polish law as the proper one.

\section{Summary}

The risk of incorrect application of both collision law instruments qualification and the public order clause - ranks high. Therefore, it can be said that the nature of their use undermines the essence of conflict law itself. On the other hand, we do not know how to understand in their case the term "incorrect". In most countries of the world, qualification is not regulated in the acts of collision law. The only information regarding the existence of such an instrument can be found in the doctrine and it is there that one should also look for guidelines on its use. However, in civil law countries, doctrine is not a source of law; therefore, all doctrinal voices can only be treated as suggestions of behaviour not binding instructions. 
Similarly, even the public order clause, regulated everywhere, can create problems in the sphere of application. It is not entirely clear how to proceed between the indication of law and the application of forum law. Should the clause in every case eliminate the application of the indicated foreign law?

Qualification may lead to elimination of the meanings of concepts unknown in the forum and the effect of the clause can almost certainly eliminate the possibility of using liberal new legal solutions influenced by changing social needs. Moreover, the interaction between qualification and the public order clause could eliminate completely the possibility of solving cases related to non-traditional marriage.

\section{R E F E R E N C E S}

Bagan-Kurluta, K. 2017. Prawo prywatne międzynarodowe. Warszawa: C. H. Beck. Bartin, E. 1897. De l'Impossibilite d'Arriver a la Suppression Definitive des Conflits de Lois. Journal du Droit International Prive $\mathcal{E}$ Jurisprudence Comparee 24: $225-255$.

Beckett, W. E. 1934. The Question of Classification ('Qualification') in Private International Law. British Yearbook of International Law 15: 46-81.

Cheshire, G. C. 1938. Private International Law. Oxford: University Press.

Despagnet, F. 1898. Des Conflits de Lois Relatifs a la Qualification des Rapports Juridiques. Journal du Droit International Prive $\mathcal{E}$ Jurisprudence Comparee 25: $253-273$.

Falconbridge, J. D. 1937. Characterization in the Conflict of Laws. Law Quarterly Review 53: 235-258.

Hayward, R. 2006. Conflict of Laws. Sydney, London: Cavendish Publishing.

Kahn, F. 1891. Gesetzeskollisionen: Ein Beitrag zur Lehre des Internationalen Privatrechts. Jhering Jahrbiicher fUr de Dogmatic des Heutigen Romischen und Deutschen Privatrechts 30: 1-143.

Lorenzen, E. G. 1920. The Theory of Qualifications and the Conflict of Laws. Columbia Law Review 20: 247-282.

Pascal, R. A. 1940. Characterization as an Approach to the Conflict of Laws. Louisiana Law Review 2, No 4: 715-728.

Pazdan, M. 2014. System prawa prywatnego. Tom 20A (ed.) Prawo prywatne międzynarodowe Warszawa: C.H. Beck.

Pazdan, M. 2017. Prawo prywatne międzynarodowe. Warszawa: Wolters Kluwer.

Robertson, A. H. 1940. Characterization in the Conflict of Law. Cambridge: Harvard University Press.

Sośniak, M. 1961. Klauzula porzadku publicznego w prawie międzynarodowym prywatnym. Warszawa: PWN. 